\title{
UPAYA MENINGKATKAN HASIL BELAJAR IPS MENGGUNAKAN MODEL PEMBELAJARAN CTL (CONTEXTUAL TEACHING ANDLEARNING) DENGAN MEDIA GAMBAR PADASDN 6 SELAT HILIR KUALA KAPUAS TAHUN PELAJARAN 2016/2017
}

\author{
Oleh : Lola Selvia*Hendri, M.Pd
}

\begin{abstract}
Penelitian ini bertujuan untuk mengetahui: (1) Mendeskripsikan aktivitas belajar peserta didik pada mata pelajaran IPS menggunakan model CTL (Contextual Teaching And Learning) dengan media gambar. (2) Peningkatan hasil belajar IPS menggunakan model CTL (Contextual Teaching and Learning) dengan media gambar. Jenis penelitian yang digunakan peneliti adalah Penelitian Tindakan Kelas (PTK).Dengan subjek dalam penelitian ini adalah seluruh peserta didik kelas V SDN 6 Selat Hilir Kuala Kapuas yang berjumlah 17 orang peserta didik 10 laki-laki dan 7 perempuan. Teknik pengumpulan data dalam penelitian ini menggunakan tes tertulis pada akhir proses pembelajaran dan observasi untuk mengetahui aktivitas pada saat proses pembelajaran. Teknik analisis data menggunakan analisis data kualitatif dan kuantitatif. Hasil penelitian menunjukkan bahwa: (1) Aktivitas belajar peserta didik dalam pembelajaran IPS dengan menggunakan model CTL (Contextual Teaching and Learning) pada kelas V SDN 6 Selat Hilir Kuala Kapuas menjadi baik. Pada siklus I aktivitas peserta didik memperoleh skor36 dengan dengan skor rata-rata 2,57 dengan kriteria cukup baik. Pada Siklus II aktivitas peserta didik memperoleh skor rata-rata 53,5 dengan skor ratarata 3,82 dengan kriteria baik. (2) Ada peningkatan hasil belajar belajar peserta didik dalam pembelajaran IPS dengan menggunakan model CTL (Contextual Teaching and Learning) pada kelas V SDN 6 Selat Hilir Kuala Kapuas. Pada pre-testdapat diketahui perolehan hasil persentase $23,53 \%$ (4 orang) peserta didik yang tuntas dan peserta didik yang tidak tuntas 70,48\% (12 orang) dengan nilai rata-rata 50. Adapun perolehan hasil pada siklus I jumlah persentase hasil belajar peserta didik mencapai 70,59\% (12 orang) peserta didik tuntas dan $23,53 \%$ (5 orang) peserta didik yang tidak tuntas dengan rata-rata nilai 72 . Pada siklus II, perolehan hasil belajar peserta didik adalah 100\% (17 orang) yang tuntas dengan rata- rata nilai 91. Ada peningkatan hasil belajar IPS dari pre test ke siklus I yaitu sebanyak $47,06 \%$ sedangkan dari siklus I ke siklus II ada peningkatan hasil belajar yaitu sebanyak 29,41\%. Ini dapat disimpulkan bahwa ada peningkatan hasil belajar dengan menggunakanmodel CTL (Contextual Teaching and Learning) pada kelas V SDN 6 Selat Hilir Kuala Kapuas.
\end{abstract}

Kata Kunci: hasil belajar, IPS, Model CTL, media gambar.

\section{PENDAHULUAN}

Pendidikan adalah proses perubahan sikap dan perilaku seseorang atau kelompok orang dalam usaha mendewasakan manusia melalui upaya pemebelajaran dan pelatihan.
Pendidikan adalah upaya manusia untuk "memanusiakan manusia “. Manusia pada hakekatnya adalah makhluk Tuhan yang paling tinggi dibandingkan dengan makhluk lain ciptaan-Nya disebabkan memiliki 
kemampuan bahasa dan akal pikiran atau rasio sehingga manusia mampu mengembangkan diri dilakukan melalui interaksi dengan lingkungannya, baiklingkungan fisik maupun lingkungan sosial. Pendidikan merupakan pilar tegaknya bangsa, melalui pendidikan bangsa akan tegak mampu menjaga martabat.

Pendidikan sebagai suatu bentuk kegiatan manusia dalam kehidupan juga menempatkan tujuan sebagai sesuatu yang hendak dicapai, baik tujuan yang dirumuskan itu bersifat abstrak sampai pada rumusan - rumusan yang dibentuk secara khusus untuk memudahkan pencapaian tujuan yang lebih tinggi.Hal ini sesuai dengan fungsi pendidikan nasional yang terdapat dalam undang-undang RI No.20 Tahun 2013 tentang sistem pendidikan nasional yang menyatakan bahwa: Sistem pendidikan nasional harus mampu menjamin pemerataan kesempatan pendidikan, peningkatan mutu serta relevansi dan efesiensi manajemen pendidikan untuk menghadapi tantangan sesuai dan tuntutan perubahan kehidupan lokal, nasional dan global sehingga perlu di lakukan pembaharuan pendidikan secara terencana, terarah dan berkesinambungan. Berbicara mengenai tujuan pendidikan nasional dalam hal ini kita akan mengkaitkannya dengan tujuan pendidikan di sekolah dasar. Mungkin tujuannya tidak jauh berbeda, dalam pendidikan sekolah dasar juga memiliki tujuan untuk mencerdaskan peserta didiknya, hanya saja di sekolah dasar pendidikan yang diberikan berupa ilmu-ilmu dasar sebagai bekal mereka untuk masuk kependidikan dengan jenjang yang lebih tinggi

Kondisi eksternal adalah kondisi yang ada di luar diri pribadi peserta didik misalnya ruang belajar yang bersih, sarana dan prasarana belajar yang memadai, media pembelajaran, model serta metode pembelajaran yang digunakan oleh pendidik.

Berbicara tentang pendidikan begitu pentingnya peranan guru dalam mensukseskan cita-cita bangsa untuk generasi penerus.Untuk itu sebagai seorang guru dituntut untuk menjadi guru profesional dan mempunyai kompetensi yang baik, profesionalisme guru menuntut guru agar bekerja dengan penuh kesanggupan, apik, dan bukan asal jadi. Karena pendidikan dalam era modern semakin tergantung pada tingkat kualitas, untuk itu perlu adanya pembaharuanpembaharuan dilingkungan yang berhubungan dengan pendidikan yang mengarahkan pada proses kegiatan pembelajaran.

Pendidikan diselenggarakan untuk menyiapkan peserta didik menjadi pribadi anggota masyarakat yang mandiri. Pribadi yang mandiri adalah pribadi yang secara mandiri mampu berpikir, menemukan dan menciptakan sesuatu yang baru, melihat permasalahan serta menemukan cara pemecahan baru yang bernalar dan lebih dapat dipertanggungjawabkan. Dengan kata lain pendidikan dapat dimaknai sebagai proses mengubah tingkah laku anak didik agar menjadi manusia dewasa yang mampu hidup mandiri dan sebagai anggota masyarakat dalam lingkungan alam sekitar dimana individu itu berada Sagala (2005:3), melainkan juga mampu melakukan perubahan dan menciptakan sesuatu yang baru. Kemandirian ini terbentuk melalui kemampuan berpikir nalar dan kemampuan berpikir kreatif yang mewujudkan kreativitas.Hal tersebut dilakukan oleh 
peserta didik dalam setiap mata pelajaran salah satunya pelajaran IPS.

IPS sebagai salah satu mata pelajaran yang ada di sekolah dasar atau madrasah ibtidaiyah, merupakan mata pelajaran yang mempelajari manusia dalam semua aspek kehidupan dan interaksinya dalam masyarakat. Pendidikan IPS sekarang ini masih perlu digalakkan, berkenaan dengan usaha meningkatkan mutu pendidikan.Persoalannya, sejauh mana pendidikan IPS dewasa ini mengembangkan potensi berpikir peserta didik dengan melalui kegiatan belajarnya. Hal ini terus mendapat perhatian karena persoalannya berkaitan dengan proses belajar mengajar dengan tujuan untuk meningkatkan kualitas proses dan hasil pendidikan IPS.Peranan IPS sangatlah penting untuk mendidik manusia mengembangkan pengetahuan, sikap, dan keterampilan agar dapat mengambil bagian secara aktif dalam kehidupannya kelak menjadi warga negara yang baik. Tujuan ini memberikan tanggung jawab yang berat kepada guru untuk menggunakan banyak pemikiran dan energi agar dapat

Masalah ini semakin serius manakala dihadapkan kenyataan bahwa selama ini mata pelajaran IPS kurang mendapatkan perhatian semestinya. Padahal dengan memahami IPSakan membimbing peserta didik menghadapi kenyataan dalam lingkungan sosialnya dan dapat menghadapi masalah-masalah sosial yang lebih arif dan bijaksana. Untuk menghadapi tantangan perubahan ini, sesungguhnya gurulah yang harus memandu peserta didik membuka cakrawala pengetahuan sosialnya.

Guru tidak lagi hanya berfungsi sebagai penyampai informasi, tetapi harus bisa menjadi pembimbing siswa dalam mengembangkan pengetahuannya dan mendapatka pembelajaran menyenangkan, bermakna dan bermutu. Guru dituntut juga untuk mengembangkan kompetensinya dalam meningkatkan kualitas pengetahuan dan kreativitas peserta didik.

Selama ini, minat belajar siswa terhadap mata pelajaran Ilmu Pengetahuan Sosial (IPS) masih tergolong sangat rendah.Oleh karena itu guru dalam mengajar dituntut kesabaran, keuletan, dan sikap terbuka di samping kemauan menciptakan situasi belajar mengajar yang lebih aktif.Demikian pula dari siswa dituntut adanya semangat dan dorongan untuk belajar. Dalam proses belajar mengajar pasti terdapat kelemahan yang mempengaruhi hasil belajar peserta didik.

Dalam pembelajaran IPS peserta didik kurang didorong untuk mengembangkan budaya sebagai kajian materi IPS kemampuan berpikir namun lebih banyak proses pembelajaran didalam kelas yang diarahkan kemampuannya untuk menghapal informasi tanpa dituntut untuk memahami informasi yang diingatnya siswa hanya menghapal konsep atau fakta belaka. Dengan kondisi pembelajaran yang seperti itu, maka akan berpengaruh pada hasil belajar peserta didik.

Berdasarkan hasil Observasi yang telah dialakukan di SDN 6 Selat Hilir yang dilakukan oleh peneliti bersama dengan guru kelas $\mathrm{V}$ bahwa hasil belajar peserta didik masih rendah, model yang kurang bervariasi, kurangnya media dalam pembelajaran sehingga peserta didik kurang ikut berpartisipasi dalam pembelajaran, mereka lebih cenderung pasif tidak mau bertanya dan tidak fokus saat proses pembelajaran berlangsung,kemampuan berpikir peserta didik yang kurang didorong untuk berkembang diketahui di SDN 6 Selat Hilir memiliki jumlah peserta didik 17 
orang, 10 laki-laki dan 7 perempuan yang diketahui hanya 6 ( 40\%) peserta didik yang mencapai KKM , sedangkan 11 (60\%) peserta didik belum mencapai KKM 60 . Sehingga diperlukan perbaikan pembelajaran IPS agar tidak tertinggal dengan pelajaran lainnya.Sumber Wali kelas V SDN 6 Selat Hilir Kuala Kapuas.

Upaya yang dilakukan untuk meningkatkan aktivitas dan hasil belajar peserta didik pada pada materi Peristiwa Sekitar Proklamasi Kemerdekaan yaitu dengan menggunakan model pembelajaran Contextual Teaching Learning (CTL) bantuan gambar"CTL adalah suatu strategi pembelajaran yang menekankan kepada prosesketerlibatan siswa secara penuh untuk dapat menemukan materi yangdipelajari dan menghubungkannya dengan situasi kehidupan nyatasehingga mendorong peserta didik untuk dapat menerapkannya dalam kehidupanmereka”.

Penerapan model CTL (Contextual Teaching And Learning) diharapkan dapat membantu siswa yang pasif menjadi aktif, menjadi lebih bermakna, mendorong keaktifan membangkitkan minat dan kreatifitas belajar peserta didik karena dalam proses pembelajaran siswa terlibat langsung sehingga dapat meningkatkan hasil belajar peserta didik dan membantu pesrta didik dalam mencapai tujuan-tujuan dari belajar IPS. dan dibantu oleh media pembelajran yang diharapkan dapat menarik minat peserta didik dalam belajar dimana media pembelajaran adalah segala sesuatu yang dapat menyalurkan pesan, dapat merangsang fikiran, perasaan, dan kemauan peserta didik sehingga dapat mendorong terciptanya proses belajar pada diri peserta didik.
Oleh karena itu, berdasarkan masalah diatas, penulis tertarik untuk mencoba melakukan tindakan perbaikan dalam pembelajaran melalui penelitian tindakan kelas (PTK), dengan judul “ Upaya meningkatkan hasil belajar IPS menggunakan model pembelajaran CTL (Contextual Teaching and Learning) dengan media gambar pada SDN 6 Selat Hilir Kuala Kapuas.

\section{TINJAUAN PUSTAKA}

\section{Hakikat Pendidikan IPS}

\section{a. Pengertian Pendidikan IPS}

Ilmu Pengetahuan Sosial (IPS) merupakan salah satu mata pelajaran yang diberikan mulai dari SD/SMP/SMA Ilmu Pengetahuan Sosial mengkaji seperangkat peristiwa, fakta, konsep, dan generalisasi yang berkaitan dengan isu sosial. Pada jenjang SD/MI mata pelajaran IPS memuat materi geografi, sejarah, sosiologi, dan ekonomi.Melalui mata pelajaran IPS, peserta didik diarahkan untuk dapat menjadi warga negara Indonesia yang demokratis, dan bertanggung jawab, serta warga dunia yang cinta damai. Menurut Hidayati (2004: 9) Ilmu Pengetahuan Sosial (IPS) pada awalnya berasal dari literatur pendidikan Amerika Serikat dengan namaSocial Studies. Sedangkan menurut Fajar (2004:110) Ilmu Pengetahuan Sosial merupakan mata pelajaran yang di dalamnya mengkaji seperangkat peristiwa, fakta, konsep, dan generalisasi yang berkaitan dengan isu sosial dan kewarganegaraan. Lebih spesifik lagi dijelaskan bahwa Ilmu Pengetahuan Sosial di Sekolah Dasar merupakan mata pelajaran yang berdiri sendiri sebagai integrasi dari sejumlah konsep disiplin ilmu sosial, humaniora, sains bahkan isu dan masalah sosial lainnya Sapriya (2009: 7).

Dari berbagai pendapat di atas dapat disimpulkan bahwa Ilmu Pengetahuan Sosial 
merupakan mata pelajaran yang merupakan perpaduan dengan ilmu-ilmu lain seperti Geografi, Ekonomi, Sejarah, Antropologi, Politik dan ilmu sosial lainnya dalam mengkaji peristiwa, fakta, konsep, generalisasi yang berkaitan dengan isu atau masalah-masalah sosial yang hadir di dalam masyarakat. Dengan demikian pelajaran IPS di Sekolah Dasar dilaksanakan secara terpadu dengan memperhatikan karakteristik peserta didik.Ilmu Pengetahuan Sosial merupakan salah satu mata pelajaran pokok pada jenjang pendidikan dasar. Keberadaan peserta didik dengan status dan kondisi sosial yang berbeda-beda tentunya akan menghadapi masalah yang berbeda pula dalam perjalanan hidupannya. Oleh karena itu, pembelajaran IPS sangatlah penting karena materi-materi yang didapatkan peserta didik di sekolah dapat dikembangkan dan diintegrasikan menjadi sesuatu yang lebih bemakna ketika peserta didik berada di lingkungan masyarakat, baik di masa sekarang ataupun di masa yang akan datang.

\section{b. Karakteristik IPS}

Karakteristik mata pelajaran IPS berbeda dengan disiplin ilmu lain yang bersifat monolitik. Ilmu Pengetahuan Sosial (IPS) merupakan integrasi dari berbagai disiplin ilmu Menurut Sapriya, dalam Hartati (2014:18) Mata pelajaran IPS memiliki beberapa karakteristik antara lain, sebagai berikut :

1. Ilmu Pengetahuan Sosial merupakan gabungan dari unsur- unsur geografi, sejarah, ekonomi, hukum dan politik, kewarganegaraan, sosiologi, bahkan juga bidang humaniora, pendidikan, dan agama.

2. Standar Kompetensi dan Kompetensi Dasar IPS berasal dari struktur keilmuan geografi, sejarah, ekonomi, dan sosiologi, yang dikemas sedemikian rupa sehingga menjadi pokok bahasan atau topik (tema) tertentu.

3. Standar Kompetensi dan Kompetensi Dasar IPS juga menyangkut berbagai masalah sosial,

4. Standar Kompetensi dan Kompetensi Dasar dapat menyangkut peristiwa dan perubahan kehidupan masyarakat dengan prinsip sebab akibat, kewilayahan, adaptasi dan pengelolaan lingkungan, struktur, proses dan masalah sosial serta upaya-upaya perjuangan hidup agar survive seperti pemenenuhan kebutuhan, kekuasaan, keadilan dan jaminan keamanan.

\section{c. Tujuan Pendidikan IPS}

Tujuan mata pelajaran IPS di Sekolah Dasar Menurut Sapriya (2009: 8) tujuan IPS adalah:

Tujuan Ilmu Pengetahuan Sosial di Sekolah Dasar adalah mengajarkan konsep-konsep dasar Sosiologi, Geografi, Ekonomi, Sejarah, dan Kewarganegaraan; mengembangkan kemampuan berpikir kritis dan kreatif, inkuiri, pemecahan masalah, dan keterampilan sosial.Selain keterangan tersebut, Ilmu Pengetahuan Sosial bertujuan untuk membangun komitmen dan kesadaran terhadap nilai-nilai sosial dan kemanusian; dan meningkatkan kemampuan kerjasama dan kompetisi dalam masyarakat baik secara nasional ataupun secara global.

Menurut Hidayati (2004: 22) mengatakan bahwa Studi sosial menitik beratkan pada perkembangan individu yang dapat memahami lingkungan sosialnya, manusia dengan segala kegiatannyadaninteraksiantaramereka., Menurut Groos dalam Solihatin dan Raharjo (2007:14) menjelaskan 
bahwa:Tujuan pendidikan Ilmu Pengetahuan Sosial untuk mempersiapkan siswa menjadi warga Negara yang baik dalam lingkungannya di masyarakat. Selanjutnya, Ilmu Pengetahuan Sosial pada dasarnya untuk membekali dan mendidik siswa berupa kemampuan dasar untuk mengembangkan minat, bakat, kemampuan dan lingkungannya untuk melanjutkan ke jenjang yang lebih tinggi.

Dari berbagai uraian di atas dapat disimpulkan bahwa tujuan diberikannya mata pelajaran IPS di Sekolah Dasar adalah untuk mengembangkan kemampuan berpikir peserta didik terhadap masalah-masalah sosial yang berkaitan dengan masyarakat setempat. Tujuan tersebut diharapkan agar peserta didik mampu memecahkan masalahmasalah sosial lainnya sebagai bentuk pengembangan atas pengetahuan yang telah dipelajari, sehingga peserta didik mampu menghadapi tantangan kehidupan dengan baik, baik di masa sekarang ataupun di masa mendatang dengan peran yang semakin komplek.

\section{Pendekatan Pembelajaran CTL}

a. Hakikat CTL (Contextual Teaching and Learnin)

Pembelajaran kontekstual adalah terjemahan dari istilah CTL (Contextual Teaching and Learning). Kata kontekstual berasal dari kata contex yang berarti "hubungan, konteks, suasana, atau keadaan". Dengan demikian kontekstual diartikan yang berhubungan dengan suasana (konteks). Sehingga CTL (Contextual Teaching and Learning) dapat diartikan sebagai suatu pembelajaran yang berhubungan dengan suasana tertentu.Menurut Nurhadi dalam Rusman (2012:190)
Model CTL (Contextual Teaching and Learning) merupakan strategi pembelajaran yang mengaitkan materi pembelajaran secara alamiah dengan dunia nyata, sehingga siswa mampu menghubungkan dan menerapkan kompetensi hasil belajar dalamkehidupan sehari-hari sehingga siswa akan merasakan pentingnya belajar, dan dapat memaknai apa yang dipelajarinya.Johnson dalam Rusman (2012:187 ) Model CTL (Contextual Teaching and Learning) adalah keterkaitan setiap materi atau topik pembelajaran dengan kehidupan nyata. Untuk mengaitkannya bisa dilakukan berbagai cara, selain karena memang materi yang dipelajari secara langsung terkait dengan kondisi faktual, juga bisa disiasati dengan pemberian ilustrasi atau contoh, sumber belajar, media dan lainnya yang terkait dan ada hubungan dengan dunia nyata.Dari definisi di atas ditarik kesimpulan bahwa CTL adalah pengajaran dan pembelajaran kontekstual didasarkan pada pengetahuan bahwa mengaitkan merupakan kegiatan alami manusia. CTL merupakan suatu cara yang tepat untuk mempersiapkan siswa kita dalam menghadapi era reformasi, perubahan instan, dan kehadiran teknologi di mana-mana. Dengan demikian pembelajaran tidak sekedar dilihat dari sisi produk, akan tetapi yang terpenting adalah proses. Oleh karena itu, tugas guru mensiasati strategi pembelajaran bagaimana yang dipandang lebih efektif dalam membimbing kegiatan siswa agar siswa dapat menemukan apa yang menjadi harapannya.

\section{b. Komponen CTL (Contextual Teaching and Learning)}


Komponen pembelajaran Kontekstual menurut Jhonson dalam Rusman (2012:192) meliputi :

1. Membangun untuk menemukan makna

Keterkaitan yang mengarah pada makna adalah jantung dari pengajaran dan pembelajaran kontekstual. Ketika murid dapat mengaitkan isi dari mata pelajaran akademik matematika, ilmu pengetahuan alam, sejarah, atau bahasa Indonesia dengan pengalaman mereka sendiri, mereka menemukan makna, dan makna memberikan mereka untuk belajar.Bisa dikatakan pengaitan yang paling ampuh adalah pengaitan yang mengundang siswa untuk membuat pilihan, menerima tanggung jawab, dan memberikan hasil yang penting bagi orang lain

2. Pembelajaran mandiri dan kerjasama.

Definisi CTL (Contextual Teaching and Learning) tentang pembelajaran mandiri sangat terkait pada pengertian"mandiri" itu sendiiri.Para pelajar yang memiliki tipe seperti itu "mengatur diri sendiri" memerintah diri sendiri.Mereka mengambil keputusan sendiri dan menerima tanggung jawab untuk itu. Pola belajar mereka juga diatur, maksudnya disesuaikan dan dilaksanakan dalam kaitannya dengan sesuatu yang lain. Mereka mengatur, menyesuaikan tindakan mereka untuk mencapai tujuan penting tertentu. Kerja sama adalah komponen penting dalam CTL. Kerja sama dapat menghilangkan hambatan mental akibat terbatasnya pengalaman dan cara pandang yang sempit. Jadi akan lebih memungkinkan untuk menemukan kekuatan dan kelemahan diri, belajar untuk menghargai orang lain, mendengar dengan pikiran terbuka, dan membangun persetujuan bersama.

3. Berpikir Kritis dan Kreatif

Berpikir kritis merupakan sebuah proses terarah dan jelas yang digunakan dalam kegiatan mental, seperti memecahkan masalah, mengambil keputusan, menganalisis asumsi, dan melakukan penelitian yang terorganisasi. Sedangkan berpikir Kreatif adalah kegiatan mental yang memupuk ide-ide asli dan pemahaman-pemahaman baru.

4. Membantu individu tumbuh kembang

Guru CTL menciptakan lingkungan belajar yang membantu murid tumbuhdan berkembang dengan mencontohkan perilaku yang benar dan sifat-sifat intelektual, sopan santun, rasa belas kasih, saling menghormati, rajin, disiplin diri,dan semangat belajar yang mereka harapkan dari para siswanya. Para guru CTL membimbing setiap siswa untuk mengembangkan kecerdasan yang mudah untuk mereka dan menumbuhkan kecerdasan yang merupakan tantangan untuk mereka.Para guru CTL mendorong mereka untuk meningkatkan kecerdasan mereka, danmengeluarkan bakat yang terpendam di dalam diri mereka.

5. kelompok berdiskusi, tanya jawab, dan lain sebagainya.

6. Mengahdirkan model sebagi contoh pemebelajaran, bisa melaui ilustrasi, 
model, bahkan media yang sebenarnya.

7. Membiasakan anak untuk melakukan refleksi dari setiap kegiatan pemebelajaran yang telah dilakukan.

8. Melakukan penilaian secara objektif, yaitu menilai kemampuan yang sebenarnya pada setiap siswa.

\section{c. Langkah-langkah Pembelajaran} CTL (Contextual Teaching and Learning)

Menurut Johnson dalam Rusman (2012: 192) adapun langkah-langkah pembelajaran CTL sebagi berikut :

a) Mengembangkan pemikiran siswa untuk melakukan kegiatan belajar lebih bermakna dengan cara bekerja sendiri, menemukan sendiri, dan mengkonstruksi sendiri pengetahuan dan keterampilanbaru yang harus dimiliki.

1. Kelebihan

a. Pembelajaran lebih bermakna dan nyata. Artinya siswa dituntut untuk dapat menangkap hubungan antara pengalaman belajar sekolah dengan kehidupan nyata. Hal ini sangat penting sebab dengan menghubungkan materi yang telah ditemukan dalam kehidupan nyata, bukan saja bagi siswa materi itu akan berfungsi secara fungsional akan tetapi materi yang dipelajarinya akan tertanam erat dalam memori siswa sehingga tidak akan mudah dilupakan

b. Pembelajaran lebih produktif dan mampu menumbuhkan penguatan konsep kepada siswa karena metode pembelajaran CTL menganut aliran konstruksivisme, dimana setiap siswa dituntun untuk menemukan pengetahuannya sendiri. Melalui landasan filosofis konstruksivisme siswa diharapkan belajar melalui mengalami bukan menghafal.

c. Menumuhkan keberanian siswa untuk mengemukakan pendapat tentang materi yang dipelajari.

d. Menumbuhkan rasa ingin tahu tentang materi yang dipelajari dengan bertanya kepada guru.

e. Menumbuhkan kemampuan dalam bekerjasama dengan teman yang lain untuk memecahkan masalah yang ada

f. Peserta didik dapat membuat kesimpulan sendiri dari kegiatan pembelajaran.

2. Kelemahan

a. Guru lebih intensif dalam membimbing karena model CTL guru tidak lagi berperan sebagai pusat informasi. Tugas guru adalah mengelola sebagai sebuah tim yang bekerja sama untuk menemukan pengetahuan dan keterampilan yang baru bagi siswa. Siswa dipandang sebagai individu yang sedang berkembang. Kemampuan belajar seseorang dipengaruhi oleh tingkat perkembangan dan kekuatan pengalaman yang dimilikinya. Dengan demikian, peran guru bukanlah sebagai instruktur atau penguasa yang memaksa kehendak melainkan guru adalah pembimbing siswa agar dapat belajar sesuatudengan tahap perkembangannya.

b. Gurumemberikankesempatankepadasisw auntukmenemukan atau menerapkan sendiri ide-ide dan mengajaksiswa agar dengan menyadari dan dengan sadar menggunakanstrategi-strategi mereka sendiri untuk belajar. Namun dalamkonteks ini tentunya guru memerlukan perhatian danbimbinganyangekstraterhadapsiswaa gar tujuanpembelajaran sesuai dengan apa yang diterapkan semula. 
Adapun penelitian ini dengan menggunakan PTK (Penelitian Tindakan Kelas).Penelitian tindakan kelas (PTK) dikategorikan penelitian yang berusaha untuk memecahkan atau menjawab permasalahan yang dihadapi pada situasi tertentu. Penelitian ini merupakan penelitian yang dilakukan di dalam kelas dan bertujuan untuk mengatasi berbagai masalah yang terjadi di kelas.

\section{HASIL DAN PEMBAHASAN}

Pembahasan hasil penelitian di kelas V SDN 6 Selat Hilir Kuala Kapuas Menggunakan Model CTL (Contextual Teaching and Learning) pada mata pelajaran IPS sebagai berikut :

1. Aktivitas Belajar Peserta Didik Kelas V SDN 6 Selat Hilir Kuala Kapuas saat Pembelajaran IPS menggunakan Model CTL (Contextual Teaching and Learning) dengan media gambar.

Berdasarkan analisis data yang dilakukan terhadap aktivitas peserta didik maka dapat diperoleh hasil aktivitas peserta didik pada setiap siklusnya. Pada Siklus I, aktivitas peserta didik memperoleh skor36 dengan dengan skor rata-rata 2,57 dengan kriteria cukup baik. Pada Siklus II aktivitas peserta didik memperoleh skor rata-rata 53,5 dengan skor rata- rata 3,82 dengan kriteria baik. Hal ini menunjukkan bahwa peserta didik lebih aktif pada saat pembelajaran IPS dengan menggunakan Model CTL (Contextual Teaching and Learning).

2. Hasil Belajar IPS Peserta Didik kelas SDN 6 Selat Hilir Kuala Kapuas Menggunakan ModelCTL (Contextual Teaching and Learning) dengan media gambar.

Berdasarkan analisis data yang dilakukan terhadap hasil belajar peserta didik, maka dapat diperoleh hasil belajar peserta didik dari tes awal, tes akhir Siklus I dan tes akhir Siklus II. Pada tes awal, hasil belajar peserta didik memperoleh nilai rata-rata-rata 50 (dibawah KKM 60) dengan ketuntasan Klasikal 23,53\% dan kriteria sangat kurang tercapai. Pada siklus I hasil belajar peserta didik memperoleh nilai rata-rata 72 dengan ketuntasan klasikal 70,59\% dan kriteria cukup tercapai. Pada Siklus II meningkat hasil belajar peserta didik memperoleh nilai rata-rata 91 dengan ketuntasan klasikal $100 \%$ dan kriteria sangat tercapai.

Hal ini diperkuat dengan penelitian yang dilakukan oleh Mirnawati (2014) dalam meningkatkan motivasi peserta didik dalam penerapan model CTL pada materiSumberDayaAlamdapat meningkatkanhasilbelajarsiswa siswakelasIVSD2BacinKudusmateriSumb erDayaAlamtahun ajaran 2013/2014. Hal ini dikarenakandalam model CTL, materi yang dipelajari peserta didik dihubungkan dengan kehidupan nyataataukehidupansehari-hari peserta didik,sehinggaakanmemperjelasmateriyan gdisajikanolehgurudan akhirnyadapatmeningkatkanhasil belajarpadamateri.

\section{KESIMPULAN}

1. Aktivitas belajar peserta didik dalam pembelajaran IPS dengan menggunakan model CTL (Contextual Teaching and Learning) pada kelas V SDN 6 Selat Hilir Kuala Kapuas menjadi baik. Pada siklus Iaktivitas peserta didik memperoleh skor36 dengan dengan skor rata-rata 2,57 dengan kriteria cukup baik. Pada Siklus II aktivitas peserta didik memperoleh skor rata-rata 53,5 dengan skor rata- rata 3,82 dengan kriteria baik.

2. Ada peningkatan hasil belajar belajar peserta didik dalam pembelajaran IPS dengan menggunakan model CTL (Contextual 
Teaching and Learning) pada kelas V SDN 6 Selat Hilir Kuala Kapuas. Pada pre-testdapat diketahui perolehan hasil persentase $23,53 \%$ (4 orang) peserta didik yang tuntas dan peserta didik yang tidak tuntas $70,48 \%$ (12 orang) dengan nilai rata-rata 50. Adapun perolehan hasil pada siklus I jumlah persentase hasil belajar peserta didik mencapai $70,59 \%$ (12 orang) peserta didik tuntas dan 23,53\% (5orang) peserta didik yang tidak tuntas dengan rata-rata nilai 72 .

\section{DAFTAR PUSTAKA}

Fajar, Arnie. 2004. Portofolio dalam Pembelajaran IPS. Bandung: Remaja Rosdakarya.

Hidayati. 2004. Pendidikan Ilmu Pengetahuan Sosial di Sekolah

Solihatin Etin dan Raharjo. 2007.

Cooperative Learning

Analisis Model

Pembelajaran IPS.

Jakarta: Bumi Aksara.

Rusman. 2012. MODEL - MODEL PEMEBELAJARAN

Mengembangkan Profesionalisme

Guru. Jakarta: PT Raja Grapindo

Persada.
Pada siklus II, perolehan hasil belajar peserta didik adalah 100\% (17orang) yang tuntas dengan rata- rata nilai 91. Ada peningkatan hasil belajar IPS dari pre test ke siklus I yaitu sebanyak 47,06\% sedangkan dari siklus I ke siklus II ada peningkatan hasil belajar yait sebanyak29,41\%. Ini dapat disimpulkan bahwa ada peningkatan hasil belajar dengan menggunakan model CTL (Contextual Teaching and Learning) pada kelas V SDN 6 Selat Hilir Kuala K

Dasar.Yogyakarta: IKIP Yogyakarta.

Kunandar. $2010 . \quad$ Guru

Profesional.Jakarta: Rajawali Press. Sapriya. 2009. Pendidikan IPS. Bandung: PT. Remaja Rosdakarya. dengan kehidupan nyata. 
Tunas Jurnal Pendidikan Guru Sekolah Dasar,Desember 2017, Volume 3 Nomor 1, (34-44) ISSN 2477-6076 